\title{
CHANGES IN PLASMA VOLUME AND CARDIAC OUTPUT FOLLOWING THE INTRAVENOUS'INJECTION OF GELATIN, SERUM, AND PHYSIOLOGICAL SALINE SOLUTION ${ }^{1}$
}

\author{
By J. P. HOLT AND P. K. KNOEFEL \\ (From the Departments of Physiology and Pharmacology, University of \\ Louisville School of Medicine, Louisville)
}

(Received for publication November 8, 1943)

There has recently been a renewed interest in the use of gelatin as a substitute for blood plasma (1 to 5). The purpose of the present study is to determine, in normal dogs, the degree to which a single large intravenous injection of gelatin solution, physiological saline solution, or serum remains in the vascular bed and to determine the effect of these injections on cardiac output.

\section{METHODS}

Dogs were anesthetized with an intravenous injection of sodium barbital, $250 \mathrm{mgm}$. per $\mathrm{kgm}$. body weight. A tracheotomy was performed and a tracheal cannula inserted. A cephalic vein, carotid artery, and a small branch of the right and left femoral arteries were exposed and cannulated. Arterial blood pressure was recorded by means of a $\mathrm{Hg}$ manometer that was connected to the carotid cannula. The cardiac output, right auricular pressure, and hematocrit were determined and, at the same time, 10 to $40 \mathrm{mgm}$. of the dye, T-1824, were injected intravenously to determine the plasma volume. One hour later, $50 \mathrm{cc}$. per $\mathrm{kgm}$. body weight of warmed gelatin solution, physiological saline solution, or serum were injected into the cephalic vein at the rate of $5 \mathrm{cc}$. per $\mathrm{kgm}$. per minute. Twenty minutes after the completion of the fluid injection, the cardiac output was determined, an "indirect" determination of plasma volume was made, and the hematocrit was determined. At $\mathbf{4 0}$ minutes after the completion of the injection, an "indirect" determination of plasma volume was made and the hematocrit was determined. At 60 minutes after the completion of the injection, the right auricular pressure, hematocrit, and cardiac output were determined, and an "indirect" determination of plasma volume was made. At the same time, 10 to $20 \mathrm{mgm}$. of dye were injected for a second "direct" determination of plasma volume. Two hundred and forty minutes after the completion of the injection, the hematocrit, right auricular pressure, and cardiac output were determined. At the same time, $10 \mathrm{mgm}$. of dye were injected intravenously for a third "direct" plasma volume determination.

1 Aided in part by a grant from the Knox Gelatine Company. The gelatin was furnished by the Knox Gelatine Company.
The plasma volume was determined by the method of Gibson and Evans (6). Arterial blood samples were drawn from a small branch of the femoral artery for determination of plasma dye content with a Klett-Summerson photoelectric colorimeter. The first sample was taken 20 minutes after the dye injection and 4 subsequent samples were taken at 10 -minute intervals.

Cardiac output was determined by means of the Fick formula. The rate of oxygen consumption was measured with a modified Benedict Roth type apparatus. This was connected to the dog by means of a tracheal cannula. Blood was collected over $\mathrm{Hg}$ without contact with air by the method of Austin et al. (7). Arterial blood was drawn from a small cannulated branch of a femoral artery. Mixed venous blood was drawn, in most experiments, from the right auricle by means of a glass cannula that passed into the right auricle by way of the right external jugular vein, and in others, from the right ventricle according to the method of Marshall (8). The oxygen content of the blood was determined on $2 \mathrm{cc}$. samples by the method of Van Slyke and Neill (9).

In most experiments, right auricular pressure was measured immediately before each cardiac output determination by means of a water manometer that was connected to the cannula which passed into the right auricle. At the end of each experiment, the position of the tip of the cannula in the auricle was determined and all right auricular pressures were referred to this level as zero.

The hematocrit was determined on arterial blood by the method of Wintrobe (10).

Clotting was prevented in blood samples by drawing the blood into tubes which contained $1.3 \mathrm{mgm}$. dry ammonium oxalate and $0.7 \mathrm{mgm}$. dry potassim oxalate per cc. of blood. All blood withdrawn from the animal was replaced by transfusion of an equal volume of blood from another dog.

The gelatin² (Lot B78-1) used in these experiments was supplied as calcium gelatinate, produced by hydrolysis of alkali-treated bovine long bone collagen. A 3.75 per cent gelatin solution was prepared by dissolving the gelatin in 0.9 per cent sodium chloride solution, and adjusting the $\mathrm{pH}$ to 7.4 by adding sodium hydroxide. The gelatin

2 A preliminary report of this work was presented at a conference on gelatin which was convened by the subcommittee on blood substitutes of the National Research Council, in Washington, D. C., Feb. 23, 1943. 
solution was autoclaved for 90 minutes at 10 pounds pressure before using. The colloidal osmotic pressure of the gelatin solution was $29 \mathrm{~mm}$. of $\mathrm{Hg}$, as measured by the method of Hepp (11).

Pooled serum was prepared from 2 to 4 dogs and refrigerated for approximately 24 hours before being used.

The blood volume (B.V.), oxygen content of $100 \mathrm{cc}$. of arterial red blood cells $\left(\mathrm{O}_{2}\right.$ R.B.C. $)$, and total peripheral resistance (T.P.R.), were calculated as follows:

$$
\begin{aligned}
\text { B.V. } & =\frac{\text { P.V. }}{\text { P.H. }} \times 100 \\
\mathrm{O}_{2} \text { R.B.C. } & =\frac{\text { A.O. }}{\text { R.H. }} \times 100 \\
\text { T.P.R. } & =\frac{\text { Pr. }}{\text { C.O. }} \times 1332
\end{aligned}
$$

P.V. is plasma volume. P.H. is the percentage of plasma in the hematocrit. R.H. is the percentage of erythrocytes in the hematocrit. A.O. is the oxygen content of $100 \mathrm{cc}$. of arterial blood. Pr. is mean arterial pressure in $\mathrm{mm}$. Hg. C.O. is cardiac output in cc. per second.

In some experiments the following supplementary data were obtained:

(1) The plasma protein content was determined by the gravimetric method (12).

(2) The plasma gelatin content was determined as hydroxyproline by the method of Macfarlane and Guest (13).

\section{OBSERVATIONS}

The results of all observations are tabulated in Tables I, II, and III.

\begin{tabular}{|c|c|c|c|c|c|c|c|c|c|c|c|c|c|c|}
\hline \multirow{2}{*}{$\begin{array}{c}\text { Expt. } \\
\text { no. }\end{array}$} & \multirow{2}{*}{$\begin{array}{l}\text { Solution } \\
\text { injected }\end{array}$} & \multirow{2}{*}{$\begin{array}{c}\text { Weight } \\
\text { of } \\
\text { dog }\end{array}$} & \multirow{2}{*}{ Time } & \multirow{2}{*}{$\begin{array}{l}\text { Plasma } \\
\text { volume }\end{array}$} & \multirow{2}{*}{$\underset{\text { tocrit }}{\text { Hema- }}$} & \multirow{2}{*}{$\begin{array}{c}\text { Blood } \\
\text { volume }\end{array}$} & \multicolumn{2}{|c|}{ Oxygen } & \multirow{2}{*}{$\begin{array}{c}\text { Oxygen } \\
\text { con- } \\
\text { sumption }\end{array}$} & \multirow{2}{*}{$\begin{array}{l}\text { Cardiac } \\
\text { output }\end{array}$} & \multirow{2}{*}{$\begin{array}{c}\text { Arterial } \\
\text { pres- } \\
\text { sure }\end{array}$} & \multirow{2}{*}{$\begin{array}{c}\text { Right } \\
\text { auricular } \\
\text { pressure }\end{array}$} & \multirow{2}{*}{$\begin{array}{c}\text { Arterial } \\
\text { oxygen }\end{array}$} & \multirow{2}{*}{$\begin{array}{c}\text { Total } \\
\text { periph } \\
\text { eral } \\
\text { resist- } \\
\text { ance }\end{array}$} \\
\hline & & & & & & & Arterial & Venous & & & & & & \\
\hline 1 & $\begin{array}{c}c c . \\
\\
0.9 \text { per } \\
\text { cent } \mathrm{NaCl} \\
750\end{array}$ & $\begin{array}{c}\mathrm{kgm} . \\
15.0\end{array}$ & $\begin{array}{r}\min \text { - } \\
\text { utes } \\
0 \\
20 \\
40 \\
60 \\
60 \\
240\end{array}$ & $\begin{array}{l}c c . \\
916^{*} \\
979 \\
933 \\
781 \\
869^{*} \\
915^{*}\end{array}$ & \begin{tabular}{|} 
per cent \\
red cells \\
22.1 \\
16.6 \\
18.4 \\
\\
21.95
\end{tabular} & $\begin{array}{c}c c . \\
1188 \\
1204 \\
1167 \\
\\
1146\end{array}$ & cc. per & ${ }_{\text {Dod }}^{100} \mathrm{cc}$. & $\begin{array}{l}c c \text {. per } \\
\text { minute }\end{array}$ & $\left|\begin{array}{l}L . \\
\text { minute }\end{array}\right|$ & $\mathrm{mm} . \mathrm{Hg}$ & mm. water & $\begin{array}{l}c c . \text { per } \\
100 \text { cc. } \\
\text { red cells }\end{array}$ & A.U. \\
\hline 2 & $\begin{array}{c}0.9 \text { per } \\
\text { cent } \mathrm{NaCl} \\
775\end{array}$ & 15.4 & $\begin{array}{r}0 \\
20 \\
40 \\
60 \\
60 \\
240\end{array}$ & $\begin{array}{c}887^{*} \\
1058 \\
1080 \\
965 \\
939^{*} \\
843^{*}\end{array}$ & $\begin{array}{l}47.3 \\
40.0 \\
\\
42.4 \\
46.0\end{array}$ & $\begin{array}{l}1718 \\
1782 \\
\\
1659 \\
1591\end{array}$ & & & & & & & & \\
\hline 3 & $\begin{array}{c}0.9 \text { per } \\
\text { cent } \mathrm{NaCl} \\
925\end{array}$ & 18.5 & $\begin{array}{r}0 \\
20 \\
40 \\
60 \\
60 \\
240\end{array}$ & $\begin{array}{c}794^{*} \\
1077 \\
986 \\
981 \\
900^{*} \\
820^{*}\end{array}$ & $\begin{array}{l}\mathbf{5 8 . 1} \\
50.0 \\
51.1 \\
51.6 \\
57.0\end{array}$ & \begin{tabular}{|l|}
1965 \\
2200 \\
2063 \\
1902 \\
1953
\end{tabular} & $\begin{array}{l}26.72 \\
23.36 \\
24.15\end{array}$ & $\begin{array}{l}18.58 \\
19.83 \\
\\
17.75\end{array}$ & $\begin{array}{l}144 \\
155 \\
\\
150\end{array}$ & $\begin{array}{l}1.77 \\
4.38 \\
\\
2.34\end{array}$ & $\begin{array}{l}146 \\
124 \\
\\
130\end{array}$ & $\begin{array}{l}-2 ;+18 \\
+18 \\
+27\end{array}$ & $\begin{array}{l}46 \\
47 \\
\\
47\end{array}$ & $\begin{array}{l}6593 \\
2253 \\
\\
4475\end{array}$ \\
\hline 4 & $\begin{array}{c}0.9 \text { per } \\
\text { cent } \mathrm{NaCl} \\
1075\end{array}$ & 21.5 & $\begin{array}{r}0 \\
20 \\
40 \\
60 \\
60 \\
240\end{array}$ & $\begin{array}{c}964^{*} \\
1269 \\
1143 \\
1029 \\
1088^{*} \\
847^{*}\end{array}$ & $\begin{array}{l}47.7 \\
40.7 \\
45.4 \\
\\
44.8 \\
49.3\end{array}$ & $\begin{array}{l}1905 \\
2140 \\
2135 \\
\\
2012 \\
1722\end{array}$ & \begin{tabular}{|l|}
22.24 \\
19.45 \\
\\
22.06
\end{tabular} & $\begin{array}{l}17.53 \\
14.65 \\
15.21 \\
\end{array}$ & $\begin{array}{l}138 \\
176 \\
\\
181\end{array}$ & $\begin{array}{l}2.93 \\
3.67 \\
\\
\\
2.63\end{array}$ & $\begin{array}{l}158 \\
162 \\
\\
139\end{array}$ & $\begin{array}{r}0 \\
+26 \\
-14\end{array}$ & $\begin{array}{l}47 \\
48 \\
\\
49\end{array}$ & $\begin{array}{l}4307 \\
3532 \\
\\
4219\end{array}$ \\
\hline 5 & $\begin{array}{c}0.9 \text { per } \\
\text { cent } \mathrm{NaCl} \\
1350\end{array}$ & 27.0 & $\begin{array}{r}0 \\
20 \\
40 \\
60 \\
60 \\
240\end{array}$ & $\begin{array}{l}1389^{*} \\
1952 \\
1747 \\
1623 \\
1770^{*} \\
1517^{*}\end{array}$ & $\begin{array}{l}51.5 \\
39.0 \\
41.4 \\
\\
41.4 \\
46.2\end{array}$ & $\begin{array}{l}2914 \\
3254 \\
3005 \\
\\
3072 \\
2845\end{array}$ & $\begin{array}{l}23.52 \\
18.41 \\
\\
19.62\end{array}$ & $\begin{array}{l}17.60 \\
16.44 \\
\\
16.02\end{array}$ & $\begin{array}{l}121 \\
112 \\
\\
108\end{array}$ & $\begin{array}{l}2.04 \\
5.67 \\
\\
2.97\end{array}$ & $\begin{array}{r}86 \\
127 \\
\\
98\end{array}$ & $\begin{array}{r}0 \\
+1 \\
+3\end{array}$ & $\begin{array}{l}46 \\
47 \\
\\
48\end{array}$ & $\begin{array}{l}3372 \\
1790 \\
\\
\\
2637\end{array}$ \\
\hline
\end{tabular}

TABLE I

The effect of intravenous physiological saline solution, serum, and gelatin solution on various circulatory factors

Effect of intravenous injection of gelatin solution, physiological saline, and serum on plasma volume, hematocrit, blood volume, arterial oxygen content, venous oxygen content, oxygen consumption, cardiac output, arterial pressure, right auricular pressure, total peripheral resistance, and arterial oxygen content of red blood cells. In all experiments, zero time represents the control determination. The other determinations are at 20, 40, 60, and 240 minutes after the completion of the fluid injection. L., liters. A.U., absolute units having the dimensions, dynes seconds $\mathrm{cm} .^{-6}$.

* Plasma volume determination by the "direct" method. All other plasma volume determinations were by the "indirect" method. 
TABLE I-Continued

\begin{tabular}{|c|c|c|c|c|c|c|c|c|c|c|c|c|c|c|}
\hline \multirow{2}{*}{$\begin{array}{c}\text { Expt. } \\
\text { no. }\end{array}$} & \multirow{2}{*}{$\begin{array}{l}\text { Solution } \\
\text { injected }\end{array}$} & \multirow{2}{*}{$\mid \begin{array}{c}\text { Weight } \\
\text { of } \\
\text { dog }\end{array}$} & \multirow{2}{*}{ Time } & \multirow{2}{*}{$\begin{array}{l}\text { Plasma } \\
\text { volume }\end{array}$} & \multirow{2}{*}{$\begin{array}{c}\text { Hema- } \\
\text { tocrit }\end{array}$} & \multirow{2}{*}{$\begin{array}{c}\text { Blood } \\
\text { volume }\end{array}$} & \multicolumn{2}{|c|}{ Oxygen } & \multirow{2}{*}{$\begin{array}{c}\text { Oxygen } \\
\text { con- } \\
\text { sumption }\end{array}$} & \multirow{2}{*}{$\begin{array}{l}\text { Cardiac } \\
\text { output }\end{array}$} & \multirow{2}{*}{$\begin{array}{c}\text { Arterial } \\
\text { pres- } \\
\text { sure }\end{array}$} & \multirow{2}{*}{$\begin{array}{c}\text { Right } \\
\text { auricular } \\
\text { pressure }\end{array}$} & \multirow{2}{*}{$\left|\begin{array}{c}\text { Arterial } \\
\text { oxygen }\end{array}\right|$} & \multirow{2}{*}{$\begin{array}{l}\text { Total } \\
\text { periph- } \\
\text { eral } \\
\text { resist- } \\
\text { ance }\end{array}$} \\
\hline & & & & & & & Arterial & Venous & & & & & & \\
\hline \multirow{3}{*}{6} & \multirow{3}{*}{$\underset{740}{\text { Serum }}$} & \multirow{3}{*}{$\begin{array}{l}\text { kgm. } \\
14.8\end{array}$} & \multirow{3}{*}{ 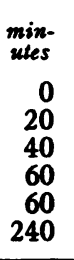 } & \multirow{3}{*}{$\begin{array}{c}c c . \\
798^{*} \\
1485 \\
1430 \\
1272 \\
1092^{*} \\
1088^{*}\end{array}$} & $\begin{array}{l}\text { per cent } \\
\text { red cells }\end{array}$ & $c c$. & \multicolumn{2}{|c|}{$\underset{\substack{\text { cc. per } \\
\text { blood }}}{100 \text { cc. }}$} & \multirow{3}{*}{$\begin{array}{c}c c . \text { per } \\
\text { minute } \\
90 \\
90\end{array}$} & \multirow{3}{*}{$\begin{array}{c}\begin{array}{c}L . \text { per } \\
\text { minute }\end{array} \\
1.01 \\
1.41 \\
\\
\\
2.10 \\
1.67\end{array}$} & \multirow{3}{*}{$\begin{array}{r}m m . H g \\
110 \\
52 \\
\\
89 \\
102\end{array}$} & \multirow{3}{*}{$\begin{array}{l}\text { mm. water } \\
-10 ;+25 \\
-25 ;-15 \\
-45 ;-40 \\
-25 ;+2\end{array}$} & \multirow{3}{*}{\begin{tabular}{|c|}
$c c$. per \\
100 cc. \\
red cells \\
48 \\
44 \\
\\
45 \\
45
\end{tabular}} & \multirow{3}{*}{$\begin{array}{l}A . U . \\
8655 \\
2957 \\
\\
3388 \\
4891\end{array}$} \\
\hline & & & & & $\begin{array}{l}49.2 \\
35.3 \\
38.0\end{array}$ & \begin{tabular}{|l|}
1578 \\
2315 \\
2321
\end{tabular} & $\begin{array}{l}23.47 \\
15.49\end{array}$ & $\begin{array}{r}14.55 \\
9.07\end{array}$ & & & & & & \\
\hline & & & & & $\begin{array}{l}39.1 \\
40.8\end{array}$ & $\begin{array}{l}1807 \\
1857\end{array}$ & $\begin{array}{l}17.47 \\
18.46 \\
\end{array}$ & \begin{tabular}{l|}
13.31 \\
13.60
\end{tabular} & & & & & & \\
\hline 7 & $\underset{1040}{\text { Serum }}$ & $20.8^{\circ}$ & $\begin{array}{r}0 \\
20 \\
40 \\
60 \\
60 \\
240\end{array}$ & $\begin{array}{l}816^{*} \\
1572 \\
1489 \\
1558 \\
1274^{*}\end{array}$ & $\begin{array}{l}58.1 \\
41.2 \\
45.2 \\
46.3 \\
52.3\end{array}$ & $\begin{array}{l}2023 \\
2720 \\
2742 \\
2411\end{array}$ & \begin{tabular}{|l|}
26.32 \\
19.42 \\
\\
20.70 \\
23.02
\end{tabular} & $\begin{array}{l}20.20 \\
15.61 \\
\\
17.38 \\
19.02 \\
\end{array}$ & $\begin{array}{l}144 \\
150 \\
\\
\\
140 \\
155\end{array}$ & $\begin{array}{l}2.36 \\
3.94 \\
\\
4.20 \\
3.88\end{array}$ & $\begin{array}{l}150 \\
131 \\
\\
\\
142 \\
166\end{array}$ & $\begin{array}{l}-7 \\
-2 \\
-5 \\
+8\end{array}$ & $\begin{array}{l}45 \\
47 \\
\\
45 \\
44\end{array}$ & $\begin{array}{l}5079 \\
2653 \\
\\
2677 \\
3420\end{array}$ \\
\hline 8 & $\underset{785}{\text { Serum }}$ & 15.7 & $\begin{array}{r}0 \\
20 \\
40 \\
60 \\
60 \\
240\end{array}$ & $\begin{array}{c}679^{*} \\
1236 \\
1198 \\
1158 \\
806^{*} \\
953^{*}\end{array}$ & $\begin{array}{l}49.2 \\
36.1 \\
37.9 \\
\\
38.6 \\
38.6\end{array}$ & \begin{tabular}{l|}
1372 \\
1971 \\
1961 \\
1334 \\
1570 \\
\end{tabular} & $\begin{array}{l}21.74 \\
16.63 \\
\\
17.02 \\
18.29 \\
\end{array}$ & $\begin{array}{l}18.45 \\
13.55 \\
\\
1.3 .86 \\
10.33 \\
\end{array}$ & $\begin{array}{r}64 \\
110 \\
\\
97 \\
77\end{array}$ & $\begin{array}{l}1.93 \\
3.57 \\
\\
3.08 \\
0.96\end{array}$ & $\begin{array}{r}144 \\
114 \\
\\
\\
124 \\
70\end{array}$ & $\begin{array}{r}-6 ;+4 \\
-4 ;+1 \\
\\
-4 ;+1 \\
-11 ;+3\end{array}$ & $\begin{array}{l}44 \\
46 \\
\\
44 \\
47\end{array}$ & $\begin{array}{l}5946 \\
2549 \\
\\
3212 \\
5810\end{array}$ \\
\hline 9 & $\underset{685}{\text { Serum }}$ & 13.7 & $\begin{array}{r}0 \\
20 \\
40 \\
60 \\
60 \\
240 \\
\end{array}$ & $\begin{array}{c}589^{*} \\
1062 \\
1032 \\
1028 \\
746^{*} \\
603^{*}\end{array}$ & \begin{tabular}{|l}
53.1 \\
50.8 \\
52.4 \\
55.8 \\
56.1
\end{tabular} & \begin{tabular}{l|}
1267 \\
2194 \\
2143 \\
\\
1700 \\
1396 \\
\end{tabular} & $\begin{array}{l}24.61 \\
17.20 \\
\\
21.43 \\
23.82 \\
\end{array}$ & $\begin{array}{l}20.42 \\
12.97 \\
\\
15.82 \\
17.10 \\
\end{array}$ & $\begin{array}{l}77 \\
96 \\
\\
91 \\
77\end{array}$ & $\begin{array}{l}2.11 \\
2.27 \\
\\
\\
1.62 \\
1.14\end{array}$ & $\begin{array}{r}148 \\
82 \\
\\
\\
115 \\
129\end{array}$ & $\begin{array}{r}-10 ;+25 \\
0 ;+20 \\
\\
-26 ;-21 \\
-24 ;-18\end{array}$ & $\begin{array}{l}46 \\
34\end{array}$ & $\begin{array}{l}5610 \\
2893 \\
\\
5682 \\
9046\end{array}$ \\
\hline 10 & $\underset{805}{\text { Serum }}$ & 16.1 & $\begin{array}{r}0 \\
20 \\
40 \\
60 \\
60 \\
240\end{array}$ & $\begin{array}{c}654^{*} \\
1277 \\
1227 \\
1129 \\
934^{*} \\
676^{*} \\
\end{array}$ & $\begin{array}{l}40.2 \\
28.6 \\
34.7 \\
40.1 \\
45.5 \\
\end{array}$ & $\begin{array}{l}1104 \\
1802 \\
1890 \\
\\
1560 \\
1257 \\
\end{array}$ & \begin{tabular}{|l|}
17.99 \\
10.82 \\
\\
31.96 \\
17.55 \\
\end{tabular} & $\begin{array}{r}14.30 \\
6.45 \\
\\
8.97 \\
10.57 \\
\end{array}$ & $\begin{array}{r}115 \\
96 \\
\\
103 \\
109\end{array}$ & $\begin{array}{l}3.12 \\
2.86 \\
\\
2.06 \\
1.57\end{array}$ & $\begin{array}{r}176 \\
96 \\
\\
\\
108 \\
130\end{array}$ & $\begin{array}{l}+6 ;+24 \\
-56 \\
-37 ;-22 \\
-7 ; 0\end{array}$ & $\begin{array}{l}45 \\
38 \\
\\
\\
35 \\
39\end{array}$ & $\begin{array}{l}4515 \\
2685 \\
\\
4188 \\
6633 \\
\end{array}$ \\
\hline 11 & $\begin{array}{c}\text { Gelatin } \\
570\end{array}$ & 11.4 & $\begin{array}{r}0 \\
20 \\
40 \\
60 \\
60 \\
240\end{array}$ & $\begin{array}{c}651^{*} \\
1119 \\
1086 \\
947 \\
1020^{*} \\
807^{*} \\
\end{array}$ & $\begin{array}{l}39.6 \\
21.6 \\
22.9 \\
26.5 \\
34.1\end{array}$ & $\begin{array}{l}1083 \\
1431 \\
1412 \\
1388 \\
1233\end{array}$ & $\begin{array}{l}18.81 \\
10.72 \\
12.78 \\
15.63 \\
\end{array}$ & $\begin{array}{r}12.59 \\
7.93 \\
\\
8.81 \\
10.67 \\
\end{array}$ & $\begin{array}{r}64 \\
68 \\
\\
67 \\
113\end{array}$ & $\begin{array}{l}1.03 \\
2.44 \\
\\
1.69 \\
2.28 \\
\end{array}$ & $\begin{array}{l}101 \\
124 \\
\\
114 \\
126\end{array}$ & $\begin{array}{r}-17 ;-10 \\
-18 ;+12 \\
-10 ;-4 \\
-4 ;+10 \\
\end{array}$ & $\begin{array}{l}48 \\
46 \\
\end{array}$ & $\begin{array}{l}7864 \\
4060 \\
\\
5394 \\
4419 \\
\end{array}$ \\
\hline 12 & $\begin{array}{c}\text { Gelatin } \\
968 \\
:\end{array}$ & 19.4 & $\begin{array}{r}0 \\
20 \\
40 \\
60 \\
60 \\
240\end{array}$ & $\begin{array}{l}846^{*} \\
1621 \\
1513 \\
1482 \\
1639^{*} \\
1267^{*}\end{array}$ & $\begin{array}{l}48.8 \\
26.8 \\
27.9 \\
26.4 \\
34.0\end{array}$ & $\begin{array}{l}1687 \\
2219 \\
2095 \\
2246 \\
1948\end{array}$ & $\begin{array}{l}21.11 \\
12.93 \\
\\
13.05 \\
15.52\end{array}$ & $\begin{array}{r}16.88 \\
10.54 \\
\\
9.92 \\
12.04 \\
\end{array}$ & $\begin{array}{l}142 \\
151 \\
\\
124 \\
150\end{array}$ & $\begin{array}{l}3.35 \\
6.31 \\
\\
3.96 \\
4.23\end{array}$ & $\begin{array}{l}144 \\
136 \\
\\
134 \\
132\end{array}$ & $\begin{array}{c}-4 ;+1 \\
+24 ;+28 \\
+28 \\
0\end{array}$ & $\begin{array}{l}43 \\
48\end{array}$ & $\begin{array}{l}3429 \\
1726 \\
\\
2701 \\
2493\end{array}$ \\
\hline 13 & $\begin{array}{l}\text { Gelatin } \\
915\end{array}$ & 18.3 & $\begin{array}{r}0 \\
20 \\
40 \\
60 \\
60 \\
240\end{array}$ & $\begin{array}{c}953^{*} \\
1759 \\
1672 \\
1558 \\
1143^{*} \\
878^{*}\end{array}$ & $\begin{array}{l}48.4 \\
32.8 \\
36.4 \\
\\
39.5 \\
48.7\end{array}$ & $\begin{array}{l}1922 \\
2646 \\
2640 \\
\\
1931 \\
1770\end{array}$ & & & & & & & & \\
\hline 14 & $\begin{array}{c}\text { Gelatin } \\
\quad 670\end{array}$ & 13.4 & $\begin{array}{r}0 \\
20 \\
40 \\
60 \\
60 \\
240\end{array}$ & $\begin{array}{l}599^{*} \\
1282 \\
1216 \\
1205 \\
1052^{*} \\
1075^{*}\end{array}$ & $\begin{array}{l}52.8 \\
35.2 \\
36.0 \\
\\
36.9 \\
46.9\end{array}$ & $\begin{array}{l}1289 \\
1988 \\
1904 \\
1676 \\
2024\end{array}$ & $\begin{array}{l}23.68 \\
16.82 \\
\\
18.04 \\
22.17\end{array}$ & $\begin{array}{l}21.27 \\
14.92 \\
\\
14.98 \\
17.51\end{array}$ & $\begin{array}{r}89 \\
142\end{array}$ & $\begin{array}{l}3.69 \\
7.50 \\
\\
3.32 \\
2.14\end{array}$ & $\begin{array}{l}128 \\
145 \\
\\
\\
142 \\
135\end{array}$ & $\begin{array}{l}-3 ; 0 \\
-12 ;+15 \\
-17 \\
-20 ;-8\end{array}$ & $\begin{array}{l}45 \\
48 \\
\\
\\
49 \\
47\end{array}$ & $\begin{array}{l}2773 \\
1542 \\
\\
3420 \\
5059\end{array}$ \\
\hline
\end{tabular}


TABLE I-Continued

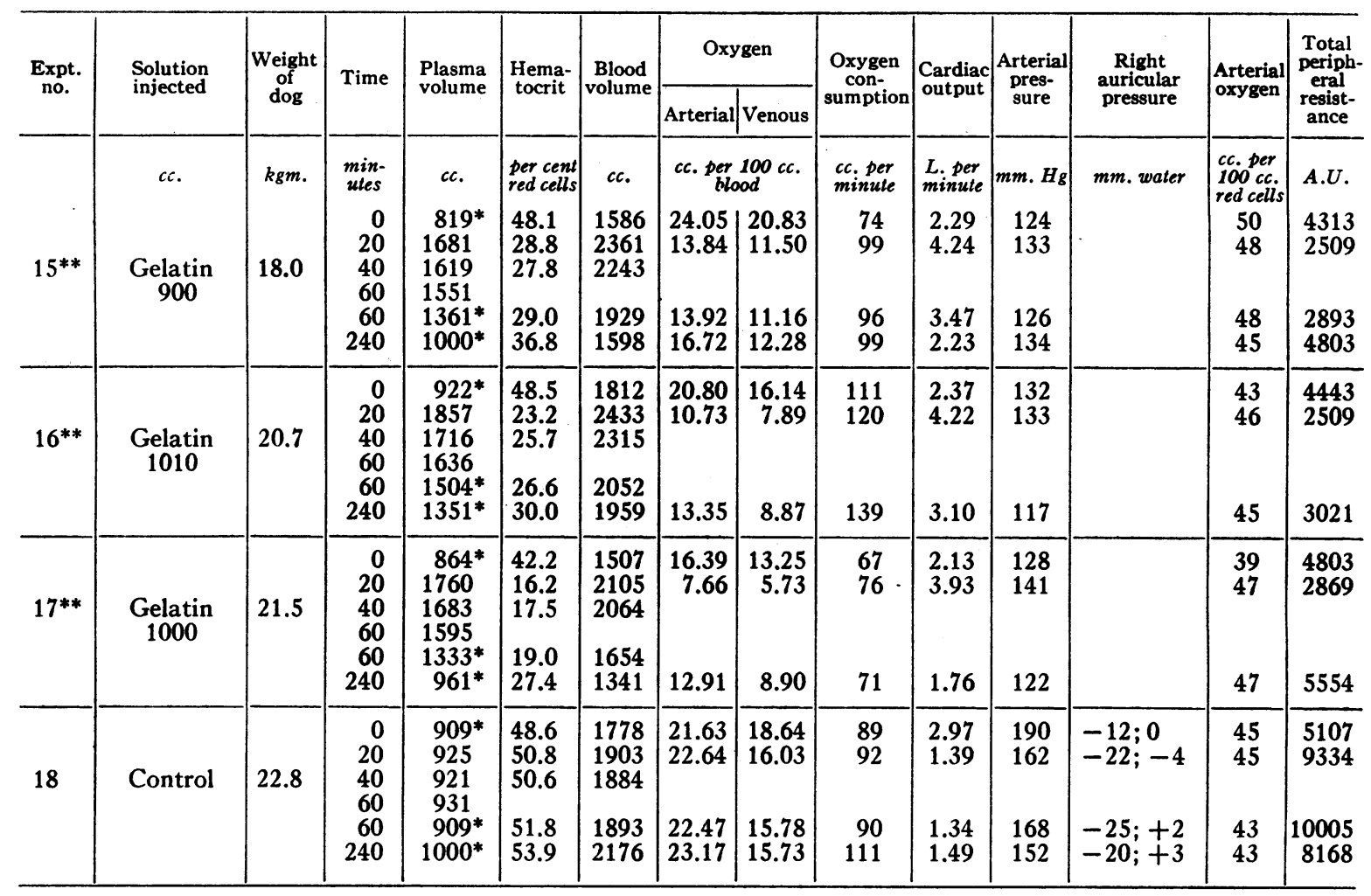

** Mixed venous blood drawn from the right ventricle. In all other experiments, mixed venous blood was drawn from the right auricle. Blood that was withdrawn was not replaced by transfusion from another dog.

The observed values for plasma volume indicated a discrepancy in the values at 60 minutes as determined by the "direct" and "indirect" methods. The average percentage by which the plasma volumes by "indirect" determination exceeded those by "direct" determination was 28 with serum, 11 with gelatin. With saline solution, the 2 values differed by only 2 per cent, which is not a real difference. For determination of the plasma volume by the "direct" method, the only requirement is that a dye concentration-time curve be obtained which, when extrapolated back to the time of injection, will give the dye concentration which would have been present if instantaneous mixing had occurred. Shifts of dye or fluid do not interfere with the satisfaction of this requirement, provided that the rates at which these occur remain constant during the period of determination. The "indirect" method of determination of plasma volume requires that the actual rate of removal of dye from the plasma be determined during the control period, and that this rate continues until the time that this "indirect" determination is made.

The probable errors in the "indirect" determination which might explain the discrepancy appeared to be (1) reduction in the optical density of the plasma, apart from its content of $\mathrm{T}-1824$, and (2) increased rate of removal of dye. The use of large amounts of dye (6) makes the first inadequate as an explanation. This was established by determination of the light transmission of serum, gelatin, and dye solutions. The second explanation is supported by the demonstration of Gregerson and Rawson $(14,15)$ of the binding of T-1824 by plasma proteins. If the theoretical dye concentration at 60 minutes is calculated on the basis that the accelerated rate of departure of plasma protein as observed produces an equal acceleration of departure of $\mathrm{T}-1824$, it agrees with the observed concentration within 6 per cent. However, the escape of fluid per se, as 0.9 per cent $\mathrm{NaCl}$, apparently does not 
TABLE II

Effect of intravenous gelatin solution and serum on plasma proteins and plasma gelatin concentration

\begin{tabular}{|c|c|c|c|c|c|c|c|c|}
\hline \multirow{2}{*}{$\underset{\text { stance }}{\text { Sub- }}$} & \multirow[b]{2}{*}{$\begin{array}{c}\text { Expt. } \\
\text { no. }\end{array}$} & \multirow{2}{*}{$\begin{array}{l}\text { Time } \\
\text { after } \\
\text { injec- } \\
\text { tion }\end{array}$} & \multirow[b]{2}{*}{$\begin{array}{l}\text { Plasma } \\
\text { protein }\end{array}$} & \multirow[b]{2}{*}{$\begin{array}{l}\text { Plasma } \\
\text { gelatin }\end{array}$} & \multirow{2}{*}{$\begin{array}{l}\text { Circu- } \\
\text { lating } \\
\text { plasma } \\
\text { protein }\end{array}$} & \multirow{2}{*}{$\begin{array}{l}\text { Circu- } \\
\text { lating } \\
\text { plasma } \\
\text { gelatin }\end{array}$} & \multicolumn{2}{|c|}{ Injected serum } \\
\hline & & & & & & & $\begin{array}{l}\text { Pro- } \\
\text { tein }\end{array}$ & $\begin{array}{l}\text { Colloidal } \\
\text { osmotic } \\
\text { pressure }\end{array}$ \\
\hline \multirow{8}{*}{ Serum } & 6 & min- & $\begin{array}{c}\text { grams } \\
\text { per } \\
100 \text { cc. }\end{array}$ & $\begin{array}{l}\text { grams } \\
\text { per } \\
100 \mathrm{cc} .\end{array}$ & $\begin{array}{c}\text { per cent } \\
\text { of } \\
\text { control }\end{array}$ & $\begin{array}{l}\text { per cent } \\
\text { of } \\
\text { amoont } \\
\text { injected }\end{array}$ & $\begin{array}{c}\text { grams } \\
\text { per } \\
100 \\
c c . \\
5.09\end{array}$ & $\begin{array}{c}\mathrm{mm} . \mathrm{Hg} \\
20.3\end{array}$ \\
\hline & 7 & & & & & & 5.45 & 24.3 \\
\hline & 8 & & & & & & 5.81 & \\
\hline & \multirow{2}{*}{9} & 0 & 6.71 & & 100 & & \multirow{2}{*}{5.33} & \multirow{2}{*}{19.3} \\
\hline & & 240 & 6.80 & & 103 & & & \\
\hline & \multirow{3}{*}{10} & 0 & 6.90 & & 100 & & \multirow{3}{*}{5.09} & \multirow{3}{*}{20.6} \\
\hline & & 60 & 6.38 & & 132 & & & \\
\hline & & 240 & 6.80 & & 102 & & & \\
\hline \multirow{15}{*}{ Gelatin } & \multirow{2}{*}{12} & 60 & & 0.70 & & 36 & & \\
\hline & & 240 & & 0.80 & & 31 & & \\
\hline & \multirow{2}{*}{13} & 60 & & 0.71 & & 27 & & \\
\hline & & 240 & & 0.83 & & 24 & & \\
\hline & \multirow{3}{*}{14} & $\mathbf{0}$ & 6.04 & 0.00 & 100 & 0 & & \\
\hline & & 60 & & 0.83 & & 39 & & \\
\hline & & 240 & 2.92 & 0.90 & 87 & 43 & & \\
\hline & \multirow{4}{*}{16} & 0 & 6.28 & & 100 & & & \\
\hline & & 20 & 3.14 & & & & & \\
\hline & & 60 & 3.33 & & 87 & & & \\
\hline & & 240 & 3.84 & & 90 & & & \\
\hline & \multirow{4}{*}{17} & 0 & 6.50 & & 100 & & & \\
\hline & & 20 & 2.76 & & & & & \\
\hline & & 60 & 3.23 & & 77 & & & \\
\hline & & 240 & 3.34 & & 57 & & & \\
\hline
\end{tabular}

At zero time, the control determinations are given. Other determinations were made at 20,60 , and 240 minutes after the completion of the fluid injection. The experiments in this table having the numbers corresponding to numbers in Table I were on the same animal.

accelerate the departure of the dye, since the "direct" and "indirect" determinations agree. In the case of gelatin, the increase in loss of dye is apparently associated with the amount of plasma protein, rather than gelatin, that leaves the blood.
The figure for plasma volume at 60 minutes obtained by the "direct" method seems more nearly to represent the true plasma volume, so that it was used in calculation of the blood volume, the percentage of change in plasma volume, and the percentage of retention of fluid. Since only "indirect" determinations of plasma volume were made at 20 and 40 minutes, these are given in the tables, although they are probably too high in the experiments with serum and gelatin.

Saline. Five experiments were performed. The plasma volume and blood volume were elevated at 20 and 40 minutes after injecting the $\mathbf{0 . 9}$ per cent sodium chloride solution but had returned nearly to the control value after 240 minutes. The plasma volume at $20,40,60$, and 240 minutes after the completion of the fluid injection was always much less than the expected plasma volume if all of the injected solution had remained in the circulation. In each experiment, the cardiac output was increased above the control at 20 minutes after the completion of the fluid injection, the average value being plus 117 per cent. After one hour, it had returned toward the control value. The total peripheral resistance was markedly decreased at 20 minutes following the fluid injection and returned toward the normal at 60 minutes after the injection. Following the injection, there was no marked effect on arterial pressure. Right auricular pressure was slightly elevated in 2 experiments and there was no change in the third. The oxygen content of $100 \mathrm{cc}$. of red cells was increased in each experiment, the average value being 2.4 per cent above the control, at 20 minutes after the completion of the injection.

Serum. Five experiments were performed with serum. The plasma volume was increased after the serum injection and had returned to a point above the control after 240 minutes. The amount of the injected serum that remained in the vascular bed was much greater at 60 and 240 minutes than the amount of saline solution that remained (Table III). In 4 of these experiments, the cardiac output was increased between 7 and 84 per cent above the control at 20 minutes after the injection. After 4 hours, the cardiac output had returned toward the control value. In 1 $\mathrm{dog}$, the cardiac output decreased throughout the experiment. The reason for this is not clear, 
TABLE III

Average percentage of change in various circulatory factors after giving saline, serum, and gelatin

\begin{tabular}{|c|c|c|c|c|c|c|}
\hline Time & $\begin{array}{l}\text { Solution } \\
\text { injected }\end{array}$ & $\mathbf{0}$ & $\begin{array}{l}20 \text { minutes } \\
\text { (percentage } \\
\text { of change) }\end{array}$ & $\begin{array}{l}40 \text { minutes } \\
\text { (percentage } \\
\text { of change) }\end{array}$ & $\begin{array}{l}60 \text { minutes } \\
\text { (percentage } \\
\text { of change) }\end{array}$ & $\begin{array}{l}240 \text { minutes } \\
\text { (percentage } \\
\text { of change) }\end{array}$ \\
\hline Plasma volume & $\begin{array}{l}\text { Saline } \\
\text { Serum } \\
\text { Gelatin }\end{array}$ & $\begin{array}{l}990 \mathrm{cc} . \\
707 \mathrm{cc} . \\
808 \mathrm{cc} .\end{array}$ & $\begin{array}{l}+27 \\
+89 \\
+96\end{array}$ & $\begin{array}{l}+19 \\
+80 \\
+86\end{array}$ & $\begin{array}{l}+11 \\
+36 \\
+61\end{array}$ & $\begin{array}{l}-1 \\
+21 \\
+32\end{array}$ \\
\hline $\begin{array}{l}\text { Percentage of injected solu- } \\
\text { tion that remained in circu- } \\
\text { lation }\end{array}$ & $\begin{array}{l}\text { Saline } \\
\text { Serum } \\
\text { Gelatin }\end{array}$ & $\begin{array}{l}975 \mathrm{cc} . \\
811 \mathrm{cc} . \\
862 \mathrm{cc} .\end{array}$ & $\begin{array}{l}+26 \\
+76 \\
+90\end{array}$ & $\begin{array}{l}+18 \\
+70 \\
+81\end{array}$ & $\begin{array}{l}+10 \\
+32 \\
+57\end{array}$ & $\begin{array}{l}-1 \\
+26 \\
+30\end{array}$ \\
\hline Blood volume & $\begin{array}{l}\text { Saline } \\
\text { Serum } \\
\text { Gelatin }\end{array}$ & $\begin{array}{l}1938 \mathrm{cc} . \\
1469 \mathrm{cc} . \\
1555 \mathrm{cc} .\end{array}$ & $\begin{array}{l}+\quad 8 \\
+52 \\
+\quad 40\end{array}$ & $\begin{array}{l}+5 \\
+53 \\
+36\end{array}$ & $\begin{array}{l}+1 \\
+21 \\
+19\end{array}$ & $\begin{array}{r}5 \\
+14 \\
+11\end{array}$ \\
\hline Cardiac output & $\begin{array}{l}\text { Saline } \\
\text { Serum } \\
\text { Gelatin }\end{array}$ & $\begin{array}{l}2.25 \mathrm{~L} \text {. per minute } \\
2.11 \text { L. per minute } \\
2.48 \text { L. per minute }\end{array}$ & $\begin{array}{l}+117 \\
+38 \\
+96\end{array}$ & & $\begin{array}{l}+22 \\
+37 \\
+36\end{array}$ & $\begin{array}{l}-4 \\
+19\end{array}$ \\
\hline Total peripheral resistance & $\begin{array}{l}\text { Saline } \\
\text { Serum } \\
\text { Gelatin }\end{array}$ & $\begin{array}{l}4757 \text { A.U. } \\
5961 \text { A.U. } \\
4604 \text { A.U. }\end{array}$ & $\begin{array}{l}-44 \\
-52 \\
-45\end{array}$ & & $\begin{array}{l}-19 \\
-32 \\
-16\end{array}$ & $\begin{array}{l}+6 \\
+1\end{array}$ \\
\hline $\begin{array}{l}\mathrm{O}_{2} \text { content of } 100 \mathrm{cc} \text {. of arterial } \\
\text { R.B.C. }\end{array}$ & $\begin{array}{l}\text { Saline } \\
\text { Serum } \\
\text { Gelatin }\end{array}$ & $\begin{array}{l}41.6 \mathrm{cc} . \\
45.7 \mathrm{cc} . \\
44.8 \mathrm{cc} .\end{array}$ & $\begin{array}{l}+\quad 2.4 \\
-\quad 8.5 \\
+\quad 8.1\end{array}$ & & $\begin{array}{l}+3.8 \\
\pm 7.5 \\
+\quad 5.1\end{array}$ & $\begin{array}{l}-4.6 \\
+4.1\end{array}$ \\
\hline
\end{tabular}

The average of the control values for the various factors are given in the zero column. The average percentage of increase $(+)$ above the control and the average percentage of decrease $(-)$ below the control of the various factors at $20,40,60$, and 240 minutes after the completion of the fluid injection are given. The total peripheral resistance is expressed in absolute units (A.U.) having the dimensions $\frac{\text { dynés sec. }}{\mathrm{cm}^{6}{ }^{6}}$ R.B.C., red blood cells.

but the fact that, at autopsy, this animal was found to have no pericardium may have significance. The arterial pressure fell markedly after the completion of the injection of the serum in 3 experiments and fell slightly in the other 2. It then returned toward the normal level. The total peripheral resistance was markedly reduced following the fluid injection and then returned toward the normal level. The right auricular pressure was less than the control value after the injection of serum in 2 experiments, and slightly greater than the control in 2 experiments. The oxygen content of $100 \mathrm{cc}$. of red blood cells was decreased in most of the experiments, the average value being a decrease of 8.5 per cent below the control, at 20 minutes after the completion of the injection.

Gelatin. Seven experiments were performed with gelatin. The plasma volume was increased after the injection and returned to a point above the control value after 240 minutes. The amount of the injected gelatin solution that remained in the vascular bed was much greater at 60 and 240 minutes than the amount of saline solution that remained (Table III). The cardiac output was increased between 78 and 138 per cent above the control value at 20 minutes after the completion of the injection and had returned toward the control value after 4 hours. There was no marked effect on arterial pressure, although there was a small rise in 6 of the experiments at 20 minutes after the injection. The total peripheral resistance was markedly reduced following the fluid injection and then returned toward the normal value. In the 3 experiments in which auricular pressure was measured, it was elevated at 20 minutes after the completion of the injection. The oxygen content of $100 \mathrm{cc}$. of red blood cells was increased in 5 of the 6 experiments in which it was measured, the average increase above the control being 8.1 per cent, at 20 minutes after the injection.

\section{DISCUSSION}

The results reported here are in agreement with those of others who have shown that physiological saline solution quickly leaves the vascular bed after intravenous injection $(16,17)$, that 
serum is retained in the vascular bed for several hours $(16,18,19)$, and that gelatin solution is retained in the vascular bed for several hours $(4$, $20,21)$. The results show that the gelatin solution is just as effective as serum in maintaining plasma volume in the normal vascular bed. Although there was, on the average, a greater percentage of retention in the vascular bed of the gelatin solution than there was of the serum, this does not necessarily mean that gelatin solution is more effective as a blood plasma substitute than serum because the colloidal osmotic pressure of the 2 solutions was different. The gelatin solution had a colloidal osmotic pressure of 29 $\mathrm{mm}$. of $\mathrm{Hg}$ while the serum had a colloidal osmotic pressure that ranged between 19.3 and $24.3 \mathrm{~mm}$. of $\mathrm{Hg}$. Thus, if the gelatin molecules stay in the vascular bed as well as the serum protein molecules do, it would be expected that a larger volume of the gelatin solution would stay in the vascular bed under these experimental conditions. From the data presented here, we do not know how effective the gelatin solution would be in maintaining the plasma volume in an abnormal vascular bed as in shock, but the use of gelatin in the treatment of shock (5) and in experimental hemorrhage (1 to 3 ) suggests that gelatin is effective in maintaining plasma volume in abnormal vascular beds.

Since blood volume and cardiac output were determined simultaneously, the results were examined for the presence of any consistent relationship between these 2 values. In 4 of the 14 experiments, a linear relationship was found, with cardiac output increasing as the blood volume increased. In 10 experiments, no consistent quantitative relationship was found, although in most cases the cardiac output was increased when the blood volume was increased. The possible errors interfering with the demonstration of a relationship include (1) erroneous values for blood volume, particularly at 20 minutes after the injection of the fluid, due to use of the "indirect" method for plasma volume, and the hematocrit for calculation of blood volume, and (2) erroneous values for cardiac output arising from the method, or changes in the cardiac output from influences other than an increase in blood volume. In 7 out of 10 control experiments, of which experiment 18 (Table I) is an example, the first output was higher than subsequent ones. The average of these determinations showed that the second output was less than the first by 33 per cent. The cause of this is not clear but may be due to the fact that the animals were anesthetized with sodium barbital. Blalock $(22,23)$ has pointed out that the cardiac output in dogs anesthetized with sodium barbital is variable and that the cardiac output during the first 90 minutes of anesthesia is generally higher than subsequent determinations. The reason for this is not clear but it may be due to the depth of the anesthesia. Since large volumes of fluid were given intravenously in each experiment, there was a tendency for the concentration of the anesthetic in the animal to be reduced as a result of the fluid injection. In most of our experiments, an attempt was made to overcome this objection by adding sodium barbital to the injected solution in a quantity that was calculated to maintain the concentration of sodium barbital constant in the animal. There is also some question as to whether mixed venous blood is obtained when blood is withdrawn from the right auricle. In some unpublished observations that we have made, it appears that in some animals, blood from different points in the right auricle may vary in oxygen content.

In spite of the fact that in control experiments the cardiac output had a tendency to be variable, the cardiac output was increased in all experiments except one at 20 minutes after the injection of fluid. This increase was greatest with saline solution, and least with serum. The mechanism responsible for this increase in cardiac output and the cause of the different degrees of increase in cardiac output when different solutions were injected are not clear. However, the increase in cardiac output was associated with a decrease in total peripheral resistance, and the decrease in peripheral resistance probably contributed to the increase in cardiac output by increasing the venous return to the heart. The decrease in peripheral resistance may have been the result of dilatation of peripheral blood vessels, the opening up of peripheral blood vessels that had been closed, a decrease in the viscosity of the blood, or any combination of these factors. Since no measurement of blood viscosity was made, we are unable to determine how much of 
the decrease in total peripheral resistance was due to viscosity change and how much was due to dilatation of blood vessels. However, the injection of saline solution would be expected to cause the viscosity of the blood plasma to decrease most, the gelatin next, and the serum least, and this is the relative order of effectiveness of these 3 solutions in increasing cardiac output. A decrease in the red blood cell concentration of the blood causes a decrease in blood viscosity. This factor would tend to cause the greatest decrease in viscosity in the gelatin experiments and the least decrease in the saline experiments.

In all of these experiments, fluid was leaving the vascular bed for 4 hours following the fluid injection. It is generally thought that the factors regulating this removal of fluid from the circulation are (1) the difference between the hydrostatic pressure on the inside of the capillaries and that in the tissue spaces, and (2) the difference between the colloidal osmotic pressure on the inside of the capillaries and that in the tissue spaces. The 0.9 per cent sodium chloride solution had no colloidal osmotic pressure; therefore, when injected, it would tend to decrease the colloidal osmotic pressure of the blood and this would tend to cause fluid to pass from the vascular bed through the capillary wall into the tissue spaces. Although the colloidal osmotic pressures of the serum and gelatin were not identical with that of plasma, these differences alone could not account for the fluid shifts observed. The alternative is that in the gelatin and serum experiments, the hydrostatic pressure in the capillaries was elevated and caused fluid to pass from the blood through the capillary wall into the tissue spaces.

The data for plasma volume and plasma protein indicate that, following the injection of blood serum, fluid and protein leave the circulation at such a rate that the protein concentration of the blood plasma remains constant. It is also shown that, following the injection of gelatin, the reduction in plasma protein content is not only from dilution, but also from disappearance of plasma protein from the circulation (average of 22 per cent lost at the 240 minute observation). The data for plasma gelatin indicate that much of it has left the circulation at 60 minutes (66 per cent of the amount injected), but suggest that the fraction remaining leaves slowly. It is of interest to note that in experiment 14 , the colloidal osmotic pressure of the plasma at the 240minute observation was maintained at $22.5 \mathrm{~mm}$. $\mathrm{Hg}$, a pressure actually higher than the value of 20.4 found before injection of the gelatin. A much lower pressure would be expected from the content of plasma protein (2.92 per cent) and gelatin (0.9 per cent) observed.

It was surprising to find that the auricular pressure changed so little when the changes in blood volume and cardiac output were so large after injecting the various solutions. In a few cases, the auricular pressure was decreased after the fluid injection, at which time the blood volume and cardiac output were increased. This may have been the result of a decrease in intrathoracic pressure or an unusually large dilatation of the vascular bed, thereby pooling blood and lowering the right auricular pressure.

It has been suggested (3) that "pseudoagglutination" of erythrocytes after the injection of gelatin might interfere with their oxygenation. We obtained no figures on arterial percentage saturation, but have calculated the oxygen content of unit volume of erythrocytes in arterial blood as possibly bearing on this point. This value was not reduced by gelatin.

\section{SUMMARY}

Plasma volume, arterial and venous oxygen content, oxygen consumption, arterial blood pressure, right auricular pressure, and the hematocrit were determined in normal barbitalized dogs, before and after the intravenous injection of $50 \mathrm{cc}$. per $\mathrm{kgm}$. body weight of 0.9 per cent sodium chloride solution, gelatin solution, and serum. Blood volume, cardiac output, total peripheral resistance, and the oxygen content of $100 \mathrm{cc}$. of arterial red cells were calculated.

Sodium chloride solution gave a small and brief increase in plasma volume. Gelatin solution and serum gave a greater and more sustained increase in plasma volume.

The injection of these solutions caused the cardiac output to increase and the total peripheral resistance to decrease.

No consistent quantitative relationship was found between blood volume and cardiac output, between blood volume and right auricular pres- 
sure, or between cardiac output and right auricular pressure.

Blood serum and a 3.75 per cent gelatin solution are about equally retained in the vascular bed, both to a greater extent than is 0.9 per cent sodium chloride.

We should like to express our thanks to Dr. W. S. Rehm for the osmotic pressure determinations, and to Dr. G. Lehmann for the determination of the plasma gelatin concentration.

\section{BIBLIOGRAPHY}

1. Waters, E. T., A comparison of isinglass and gelatin as blood substitutes. Canad. M. A. J., 1941, 45, 395.

2. Gordon, H., Hoge, L. J., and Lawson, H., Gelatin as a substitute for blood after experimental hemorrhage. Am. J. M. Sc., 1942, 204, 4.

3. Ivy, A. C., Greengard, H., Stein, I. F., Grodins, F. S., and Dutton, D. F., The effect of various blood substitutes in resuscitation after an otherwise fatal hemorrhage. Surg., Gynec. and Obst., 1943, 76, 85.

4. Little, J. M., and Dameron, J. T., Plasma retention, urinary excretion and effect upon circulating total red cell volume of intravenous gelatin in normal dogs. Am. J. Physiol., 1943, 139, 438.

5. Parkins, W. M., Koop, C. E., Riegel, C., Vars, H. M., and Lockwood, J. S., Gelatin as a plasma substitute: with particular reference to experimental hemorrhage and burn shock. Ann. Surg., 1943, 118, 193.

6. Gibson, J. G., II, and Evans, W. A., Jr., Clinical studies of the blood volume. I. Clinical application of a method employing the azo dye "Evans Blue" and the spectrophotometer. J. Clin. Invest., 1937, 16, 301.

7. Austin, J. H., Cullen, G. E., Hastings, A. B., McLean, F. C., Peters, J. P., and Van Slyke, D. D., Studies of gas and electrolyte equilibria in blood. 1. Technique for collection and analysis of blood, and for its saturation with gas mixtures of known composition. J. Biol. Chem., 1922, 54, 121.

8. Marshall, E. K., Jr., Studies on the cardiac output of the dog. I. The cardiac output of the normal unanesthetized dog. Am. J. Physiol., 1926, 77, 459.

9. Van Slyke, D. D., and Neill, J. M., The determination of gases in blood and other solutions by vacuum extraction and manometric measurement. J. Biol. Chem., 1924, 61, 523.

10. Wintrobe, M. M., A simple and accurate hematocrit. J. Lab. and Clin. Med., 1929, 15, 287.

11. Hepp, O., Ein neues Onkometer zur Bestimmung des kolloidosmotischen Druckes mit gesteigerter Messgenauigkeit und vereinfachter Handhabung. Ztschr. f. d. ges. exper. Med., 1936, 99, 709.

12. Peters, J. P., and Van Slyke, D. D:, Quantitative Clinical Chemistry. Williams and Wilkins, Baltimore, 1932, vol. 2, p. 688.

13. Macfarlane, W. D., and Guest, G. H., A new colorimetric method for the determination of hydroxyproline and its application to gelatin hydrolyzates. Canad. J. Research, Section B, 1939, 17, 139.

14. Gregersen, M. I., and Rawson, R. A., The disappearance of T-1824 and structurally related dyes from the blood stream. Am. J. Physiol., 1943, 138, 698.

15. Rawson, R. A., The binding of T-1824 and structurally related diazo dyes by the plasma proteins. Am. J. Physiol., 1943, 138, 708.

16. Amberson, W. R., Blood substitutes. Biol. Rev., 1937, 12, 48.

17. Yeomans, A., Porter, R. R., and Swank, R. L., Observations on certain manifestations of circulatory congestion produced in dogs by rapid infusion. J. Clin. Invest., 1943, 22, 33.

18. Blalock, A., Beard, J. W., and Thuss, C., Intravenous injections. A study of the effects on the composition of the blood of the injection of various fluids into dogs with normal and with low blood pressures. J. Clin. Invest., 1932, 11, 267.

19. Freeman, N. E., and Wallace, W. McL., The effect of concentrated serum on plasma volume and serum protein concentration. Am. J. Physiol., 1938, 124, 791.

20. Wolfson, W. L., and Teller, F., The intravenous use of gelatin solution in hemorrhage. Am. J. M. Sc., 1929, 178, 562.

21. Adolph, E. F., Gerbasi, M. J., and Lepore, M. J., Redistributions of water following transfusions and infusions. Am. J. Physiol., 1934, 107, 647.

22. Blalock, A., Mechanism and treatment of experimental shock. I. Shock following hemorrhage. Arch. Surg., 1927, 15, 762.

23. Johnson, G. S., and Blalock, A., Experimental shock. 12. A study of the effects of hemorrhage, of trauma to muscles, of trauma to the intestines, of burns and of histamine on the cardiac output and blood pressure of dogs. Arch. Surg., 1931, 23, 855. 